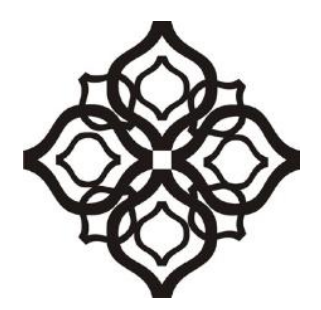

Shirkah

Journal of Economics and Business 
Shirkah: Journal of Economics and Business

Volume 5, No. 3, September-December 2020

ISSN: 2503-4235 (p); 2503-4243 (e)

\section{Table of Contents}

Institutional Quality and Sukuk Development: A Study of Five 286 OIC Countries

Nuhbatul Basyariah, Hadri Kusuma, Ibnu Qizam

Performance of GoFood MSEs Partnership: An Integration of

Entrepreneurial Orientation, Marketing Capabilities, and

Brand Orientation

Septi Kurnia Prastiwi, Asep Maulana Rohimat

Islamic Social Reporting Disclosure of Sharia Commercial

Banks in Indonesia: A Form of Social Responsibility

Riduwan, Lu'liyatul Mutmainah, Rofiul Wahyudi

Concentration and Specialization of Economic Activities in the 362

Kingdom of Saudi Arabia

Salim Bourchid Abdelkader, Hamidouche M'hamed, Abderrazak

Ahmed Zian

Indonesian Islamic Commercial Banks' Efficiency: A Stochastic 386 Frontier Analysis

Sylva Alif Rusmita, Devy Ariesta Putri

Islamic Economics Development in Indonesia: Reflection on

Contemporary Thoughts of Muslim Intellectuals

Zainal Abidin 


\title{
Islamic Social Reporting Disclosure of Sharia Commercial Banks in Indonesia: A Form of Social Responsibility
}

\author{
Riduwan \\ Faculty of Islamic Studies, Universitas Ahmad Dahlan, Indonesia \\ riduwan@pbs.uad.ac.id \\ Lu'liyatul Mutmainah* \\ Faculty of Islamic Economics and Business, UIN Sunan Kalijaga Yogyakarta, Indonesia \\ *Corresponding author: sakinah.lym@gmail.com \\ Rofiul Wahyudi \\ Faculty of Islamic Studies, Universitas Ahmad Dahlan, Indonesia \\ rofiul.wahyudi@pbs.uad.ac.id
}

\begin{abstract}
Sharia industry development encourages experts to design Corporate Social Responsibility (CSR) disclosure index that is more compatible with the characteristics of sharia-based corporate. However, studies examining CSR disclosure using Islamic Social Reporting (ISR) index that focuses on detailed results of content analysis from time to time still remains a paucity of evidence. Hence, this study aims to examine the practice of Islamic Social Reporting disclosure of sharia commercial banks in Indonesia. Drawing on the data obtained from CSR reports established by sharia banks in Indonesia, the results of content analysis disclosed that the ISR disclosure showed a fluctuating trend. It was also revealed that the six themes of ISR index have not been optimally disclosed. ISR disclosures of sharia banks in Indonesia were categorized as good since the average disclosure reached $50 \%$ in 2015 up to 2017, especially the corporate governance disclosure. This study's results imply that it is necessary to increase the disclosures that can be strengthened by regulations from financial regulators and Islamic banking associations to increase public trust and value-added of sharia commercial banks. This study contributes to the development of sharia banks as fruitful insights on policy recommendations for Islamic banks' top management.
\end{abstract}

Keywords: Corporate Social Responsibility; Islamic Social Reporting Disclosure; Sharia Commercial Banks 


\section{Introduction}

The concept of Corporate Social Responsibility (CSR) is continuing to develop in the business and economic world. Any relevant activity to CSR must be disclosed in the corporate's annual report as proof of real CSR practice in the business (Qoyum et.al., 2017). The practice is expected to give sustainable and direct effects on the improvement of social welfare and poverty alleviation. Putri (2014) stated that the main idea of CSR is to create triple bottom-line concept, consisting of finance, social, and environment.

The main goal set in the CSR concept is sustainable development. Elkington (1997) argues that sustainability is the principle ensuring the action to not to limit any environmental, social, and economic options available for the future generation. The concept, which is triplebottom-line based, forbids corporates to be financial-performance oriented (single bottom line). Corporates should perform the CSR disclosure which includes 3P (Profit, People, and Planet) as information given to their stakeholders.

The CSR disclosure has been implemented in the capital market. For example, New York Stock Exchange with its Dow Jones Sustainability (DJSI), London Stock Exchange with its Socially Responsible Investment (SRI), Financial Times Stock Exchange (FTSE) with its FTSE4Good, Hanseng Stock Exchange, and Singapore Stock Exchange (Indriantoro, 2014; Effendi, 2009). In Indonesia, the act No. 40 year 2007 on Limited Liability Companies requires a report from CSR activities (Jati et.al, 2020).

Islamic banking industries should be managed by following sharia principle. The main source to analyze and evaluate operational activities and financial performance from Islamic banks comes from the annual report that also consist of CSR activities (Putri et al., 2019). The CSR disclosure and reporting practices have been also implemented by numerous public corporates and financial institutions in Indonesia and other countries, i.e. Malaysia and Singapore. The Financial Service 
Authority settled a new regulation of OJK Number 51/POJK.03/2017 on Implementation of Sustainable Finance in Financial Service Institution, Issuer, and Public Corporate. In other words, corporates under the supervision of the Financial Service Authority are requested to submit the sustainability report (Otoritas Jasa Keuangan, 2017). Due to the binding regulation, Indonesia has become one of the developing countries which have a more advanced implementation of CSR disclosure.

Jati et al., (2020) state that Indonesian Islamic banking system is in a growing stage and it is led to the emergence of ethic in disclosing social responsibility. Islamic banking as a sharia-based company should give more transparency by disclosing all activities including CSR. The main goal of Islamic economics is falah (well-being) in the world and hereafter (Nasution et.al, 2006). Hence, Islamic banking as a part of Islamic economics should give more benefit for societies and environments by doing CSR activities.

Kamla \& Rammal (2013) state that an Islamic bank is expected to disclose detail information about activities based on sharia principle and support social welfare. Chapra \& Ahmed (2002) believe that most customers of sharia financial institution may withdraw their fund due to incompatibility between the banking system and the sharia principle. Meanwhile, Haniffa (2002) suggests a full disclosure of the reliable and relevant financial report. The disclosure is expected to assist Muslim stakeholders in making a decision. The decision covers both economic and religious aspects, so Islamic corporates may manage its responsibility to God and public (Othman \& Thani, 2010). Based on the act No. 21 year 2008 and AAOIFI (Accounting and Auditing Organization for Islamic Financial Institution), doing social function becomes one of the roles of Islamic banks (Meutia \& Febrianti, 2017).

A corporate generally uses Global Reporting Initiative (GRI) index to observe the CSR disclosure level (Nurkhin, 2010; Trisnawati, 2014; Qoyum et al., 2017). However, GRI index is not representative for 
Islamic based corporates (Firmansyah, 2014). The sharia industry development encourages the experts to design CSR disclosure index which is more compatible with the characteristics of sharia-based corporate. Haniffa (2002) is the first resarcher who designed a more relevant index to sharia-based corporate, which is called as Islamic Social Reporting (ISR). Hereafter, several researchers have started to develop the index. For instance, Othman and Thani (2010) analyzed the index containing 43 items, Sofyani et al. (2012) with 38 items, and other previous researchers also developed the ISR index (Bukair \& Rahman, 2015; Farook, Hasan, \& Lanis, 2011; Mosaid \& Boutti, 2012).

Research on CSR disclosure has been continuously conducted and resulted in various conclusions (Jati et al., 2020; Lidyah et al., 2019; Putri et al., 2019; Wardani \& Sari, 2018; Meutia \& Febrianti, 2017; Qoyum et al., 2017; Asriati et al., 2016). However, studies examining CSR disclosure using ISR index that focuses on detailed results of content analysis from time to time still remains a paucity of evidence. Therefore, this study sheds some light on the level of corporate social responsibility disclosure of Islamic banks in Indonesia using the Islamic Social Reporting (ISR) approach. The aims of this study is to elaborate and analyze the result of ISR index in Islamic banking to see how the Islamic banks disclose CSR activities with Islamic perspective. This is important to know ISR index for the stakeholder point of views to see how the sharia principles was applied in the operational activities.

\section{Review of Literature}

\section{Stakeholder Theory}

The stakeholder theory conveys that corporate should be managed for the sake of the shareholder and stakeholder. The stronger the stakeholder status, the corporate should make a tighter customization (Gray et al., 1995). According to the theory, the corporate success greatly relies on the corporate ability to balance any interests shown by investors, creditors, suppliers, customers, employees, 
governments, and communities (Jati et al., 2020; Lidyah et al., 2019). Grais \& Pellegrini (2006) concludes that Islamic banks should maintain a characteristic focused on two main goals, i.e. compliance with the sharia principle and provision of the best service.

Stakeholder theory shows that CSR disclosure is a way to communicate with stakeholder. The company has a role to the stakeholders; therefore company will implement CSR voluntarily. The right implementation of CSR will lead stakeholders' desires to be accommodated well in generating good relationship between company and stakeholders (Jati et al., 2020). In Islamic term, stakeholders are those blessed with risky ownership as the consequence of corporate action, either deliberate or non-deliberate (Iqbal \& Mirakhor, 2004). The Islamic economists confirm that the stakeholder interest is not only in the financial aspect, but also in other aspects such as ethics, religion, and other moral values (Abdullah, 2010). As a result, Islamic Social Reporting (ISR) approach consists of not only financial information, but also other aspects such as human resources, ethics, religion, socials, and environments. The disclosure of corporate social responsibility is targeted to meet the demand for accountability and transparency requested by stakeholders and thus it builds their trust.

\section{Disclosure of Corporate Social Responsibility and Islamic Social Reporting}

According to the World Business Council on Sustainable Development (WBCSD), corporate social responsibility constitutes corporate commitment to maintain ethics in behavior and contributes to the sustainable economic development (Effendi, 2009; Putri et al., 2019). Elkington (1997) conveys that reporting system discloses corporate social responsibility (CSR) information as the triple bottom line reporting or the report which discloses the information about the corporate social, environmental, and economic performance. 
Research on CSR disclosure using the Islamic Social Reporting (ISR) index was firstly conducted by Haniffa (2002). She conducted exploring research on CSR disclosure according to the Islamic perspective. She explains that Islamic CSR disclosure should be distinguished and further suggests to use sharia framework while disclosing ISR. It was aimed to manifest the corporate transparency and accountability to God and to communities (Haniffa, 2002). Meutia \& Febrianti (2017) state that the concern in ISR is not only about social justice but also beyond reporting on the environment, minority interest, and employee. Haniffa (2002) describes the monotheismbased ISR sharia framework which is then generated into ethics and sharia concept. Based on Haniffa (2002), ISR index disclosure includes five themes, i.e. finance and investment, product, employee, community, and environment and must be in accordance to the Islamic perspective.

The ISR concept is continuously developed, especially in Malaysia. The themes are not only limited to the five themes mentioned by Haniffa (2002). Othman \& Thani (2009) have added another item, that is corporate governance disclosure. They found several factors influencing ISR such as corporate size, profitability, and board composition. Type of industry is not included in the factors influencing ISR. Othman \& Thani (2010) developed the previous research by examining 56 non-financial corporate samples included in the 100 largest corporates in Bursa Malaysia in 2004-2006. They widely observed the ISR index disclosure conducted by the sharia-based nonfinancial corporates in 2004-2006. Furthermore, they figured out the minimum corporate disclosure area and lack of accountability and transparency as recommended by the Islamic principle.

Tapanjeh (2009) states that the highest accountability should not only be paid to the human being but also to God. The full disclosure principle in accounting expects the financial report to disclose full information. The principle is then modified by other set standards. Harahap (2011) states that there are three types of disclosure in general, 
i.e. full disclosure, adequate disclosure, and fair disclosure. The standard accounting is conservative, as it requests adequate disclosure only (Harahap, 2011). However, social disclosure is important because it can be considered as a way for communication between stakeholders in the company (Jati et al., 2020; Lidyah et al., 2019).

According to Maali et al. (2006), ISR has three main objectives; they are to show compliance with sharia principles, clarivy the effect of activities on public welfare, and help Muslim to perform religious obligation. These objectives remind the Islamic institution to run business fairly both for inside and outside parties (stakeholder and shareholder). Besides, social activities also encourage public to give good responses for the existence of the institution, and of course this is in line to Islamic teachings and principles (Jati et al., 2020; Lidyah et al., 2019).

Previous studies about ISR index has been conducted with numerous results. Research that focused on ISR index on Islamic banking in Indonesia have also been carried out in comparation to Malaysian Islamic banking and stated that social performance of Indonesian Islamic banking was inferior (Asriati et al., 2016; Sofyani et al., 2012). Arshad et al. (2012) also conducted a research on Islamic corporate social responsibility that related to reputation and performance on Islamic banks in Malaysia for three years (2008-2010). The results show that CSR both activities and disclosures in Islamic perspectives are crucial business strategies to give superior sustainable performance. A study conducted by Saridona \& Cahyandito (2015) focused on analysing social performance of Islamic banking in Indonesia in 2013. The result indicated that Islamic bank in Indonesia is in 'good' category with the ISR index $61.73 \%$. Meanwhile, Sawitri et al. (2017) evaluated the ISR index of Indonesian Islamic banks between 2015 and 2016. The result indicated that Bank Muamalat Indonesia had the highest score.

Moreover, Jati et al. (2020) conducted research about the effect of financial performance on ISR. The research used 44 items to measure 
ISR index of 10 Islamic banks. However, the research did not provide comprehensive analysis about the ISR index, because it focused on its relationship with financial performance. Another previous research from Putri et al., (2019) analyzed factors that affected ISR in six Islamic banks on the stock exchange with 48 index points of ISR. This research concluded that on average from 2013 to 2017, the highest score of ISR index was obtained by Bank Muamalat Indonesia and there was no influence from profitability and leverage to ISR index (Putri et al., 2019). Wardani \& Sari (2018) studied the impact of financial performance and good corporate governance on ISR index of Islamic banks in Indonesia and Malaysia from 2014 to 2016. The results showed that Bank Muamalat Indonesia reached the highest score and Bank Mandiri Syariah had the lowest score of the ISR index. However, it was also depicted that ISR disclosure in Malaysia was higher than in Indonesia. In a similar direction, Othman et al., (2009) argue that sharia-based principle will disclose more relevant information about ISR. The ISR index is the reference of social responsibility which includes the compilation of CSR standards by AAOIFI (Accounting and Auditing Organization for Islamic Financial Institution). Researchers then investigated what CSR items which should be disclosed by the sharia-based corporate were (Saridona \& Cahyandito, 2015).

Based on the explanation of relevant research on CSR disclosure, research about ISR index that focuses on detailed description of content analysis from time to time still remains unexplored. Most of the previous research have focused on the effect of various variables to the ISR index (Jati et al., 2020; Lidyah et al., 2019; Putri et al., 2019; Qoyum et al., 2017) or compared with another country (Asriati et al., 2016; Meutia \& Febrianti, 2017; Wardani \& Sari, 2019). There was a research that analyze about ISR index in Islamic bank but only for two years (2015-2016) (Sawitri et al., 2017). Therefore, the authors are interested in examining the CSR disclosure by means of Islamic Social Reporting (ISR) index. The authors consider Islamic commercial banks in 
Indonesia in 2015-2017 as the sample. Three years period that used in this research can potentially explain the change of ISR index.

\section{Research Method}

\section{Sample Selection and Data Sources}

This study's population was CSR reports established by sharia commercial banks in Indonesia from 2015 to 2017. This study was conducted in three years to see if any change in that periods. This study made use of purposive sampling method, a sampling technique with certain consideration (judgment sampling). The consideration of this sampling is because the research needs complete information of CSR disclosure so that the authors should use purposive sampling method based on the annual reports or other types of reports provided by companies that were related to CSR. Two criteria of the sample were considered. First, Islamic commercial banks in Indonesia which issued annual report, financial statement, or management report per December in the year of 2015 to 2017 and published them in succession. Second, Indonesian Islamic commercial banks which provided information about social responsibility, corporate governance, or sustainability report in 2015 to 2017.

\section{Instrumentation and Data Collection}

The data of this study were documents in the forms of annual reports, corporate governance reports, social responsibility reports, sustainability reports, and other relevant documents of sharia commercial banks' social activities from 2015 to 2017. This study employed documentation and literary study to gather the required data. The literary study was conducted by processing data from relevant literature, books, journals, previous research, and other media. Meanwhile, the documentation method was administered by collecting the annual reports, corporate governance reports, and sustainability reports that became the sample of this study. 


\section{Data Analysis}

The level of social responsibility disclosure in the annual reports of Islamic banks was measured using the ISR index score acquired using content analysis. Content analysis is a research technique for the objective, systematic, and quantitative description of the manifest content of communication (Bengtsson, 2016). It was aimed to identify the specific information or characteristics of the document, resulting in a systematic and objective description. Content analysis is a method of collecting research data through observation and analyzing the content of the document (Indriantoro \& Supomo, 2014). Content of communication in this study can be seen from the annual reports or other report documents from Islamic banking institutions in Indonesia.

The authors made use of the ISR index list referred to Othman et al. (2009), since it is more representative than the first one conducted by Haniffa (2002). The ISR index is more appropriate for Islamic banking industry rather than CSR index from GRI (Qoyum et al., 2017; Wardani \& Sari, 2019). There are six categories in ISR index, i.e. finance and investment, service and product, worker, social, environment, and corporate governance. The categories are associated with other relevant complementing sources, resulting in 48 disclosure items. The measurement was conducted by scoring. When a certain item was disclosed, score 1 was given, and 0 was provided when there was no disclosure. The scores were summed and divided by the total item in the ISR index.

ISR $=$ The number of the disclosed item

The total item in the ISR Index

\section{Results}

\section{Sample Description}

This study's object were financial reports established by Islamic commercial banks in Indonesia from 2015 to 2017. The reports were 
accessible and met the criteria of an annual report. Sampling was conducted using the purposive sampling method. The authors acquired eleven Islamic commercial banks as the research objects (see table 1).

Table 1. Islamic Commercial Banks in this Study

\begin{tabular}{ll}
\hline Islamic Commercial Banks & Status of the Reports \\
\hline Bank Syariah Bukopin (BSB) & Complete \\
Bank Central Asia Syariah (BCA_S) & Complete \\
Bank Muamalat Indonesia (BMI) & Complete \\
Bank Maybank Syariah Indonesia & Complete \\
(BMSI) & Complete \\
Bank Mega Syariah (BMS) & Complete \\
Bank Negara Indonesia Syariah & \\
(BNI_S) & Complete \\
Bank Rakyat Indonesia Syariah & \\
(BRI_S) & Complete \\
Bank Syariah Mandiri (BSM) & Complete \\
Bank Jabar Banten Syariah (BJBS) & Complete \\
Bank Panin Dubai Syariah (BPDS) & Complete \\
Bank Victoria Syariah (BVS) & Complete, but the bank was \\
Bank Tabungan Pensiunan & focused on the retirement saving \\
Nasional Syariah (BTPNS) & Currently converted, officially \\
Bank Aceh Syariah & becomes an Islamic commercial \\
& bank since 2018 \\
Currently converted, officially \\
becomes an Islamic commercial \\
bank since 2018
\end{tabular}

There were fourteen Islamic commercial banks in 2015-2017 that could be this research objects. However, there were three Islamic commercial banks which could not be analyzed further. The banks were Bank Tabungan Pensiunan Nasional Syariah which had a special 
segment and Bank Aceh Syariah as well as BPD NTB Syariah which had been currently converted and officially a Islamic commercial bank since 2018. As a result, the authors found thirty three data in three-year period of observation.

\section{Islamic Social Reporting Disclosure of Sharia Banks in Indonesia}

Content analysis was used to measure the Islamic Social Reporting (ISR) index in the annual reports, governance reports, and sustainability reports of Islamic banks in Indonesia in 2015-2017. The result of content analysis on the percentage of ISR index in the Islamic commercial banks in three years is presented in figure 1.

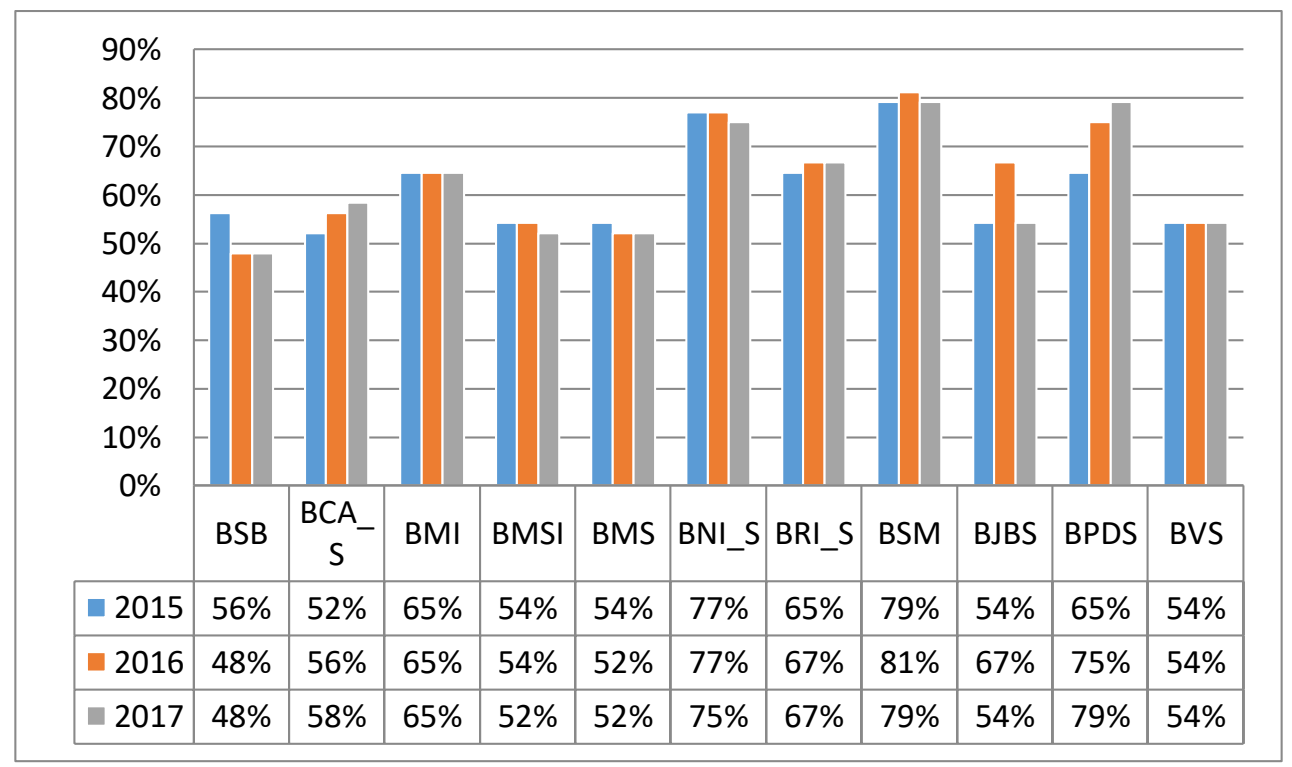

Figure 1. Trend of Sharia Banks' ISR Index in 2015-2017

Based on Figure 1, the trend of ISR index disclosure of the Islamic banks varied. Bank Syariah Bukopin (BSB), Bank Maybank Syariah Indonesia (BMSI), Bank Mega Syariah (BMS), and Bank Negara Indonesia Syariah (BNIS) showed an insignificant decline in 2017. Meanwhile, Bank Central Asia Syariah (BCAS), Bank Rakyat Indonesia Syariah (BRIS), and Bank Panin Dubai Syariah (BPDS) indicated a 
continuous increase. The increase was significant especially in Bank Panin Dubai Syariah (BPDS), after its transformation from Bank Panin Dubai Syariah (BPDS) in 2016. Moreover, the trend in Bank Syariah Mandiri (BSM) and Bank Jabar Banten Syariah (BJBS) was fluctuating but constant in Bank Victoria Syariah (BVS). The top 3 commercial banks in 2017 were Bank Syariah Mandiri, Bank Panin Dubai Syariah, and BNI Syariah. The three banks had been above $75 \%$ of the ISR index. Furthermore, figure 2 depicts the ISR index disclosure in the eleven commercial banks in 2015-2017.

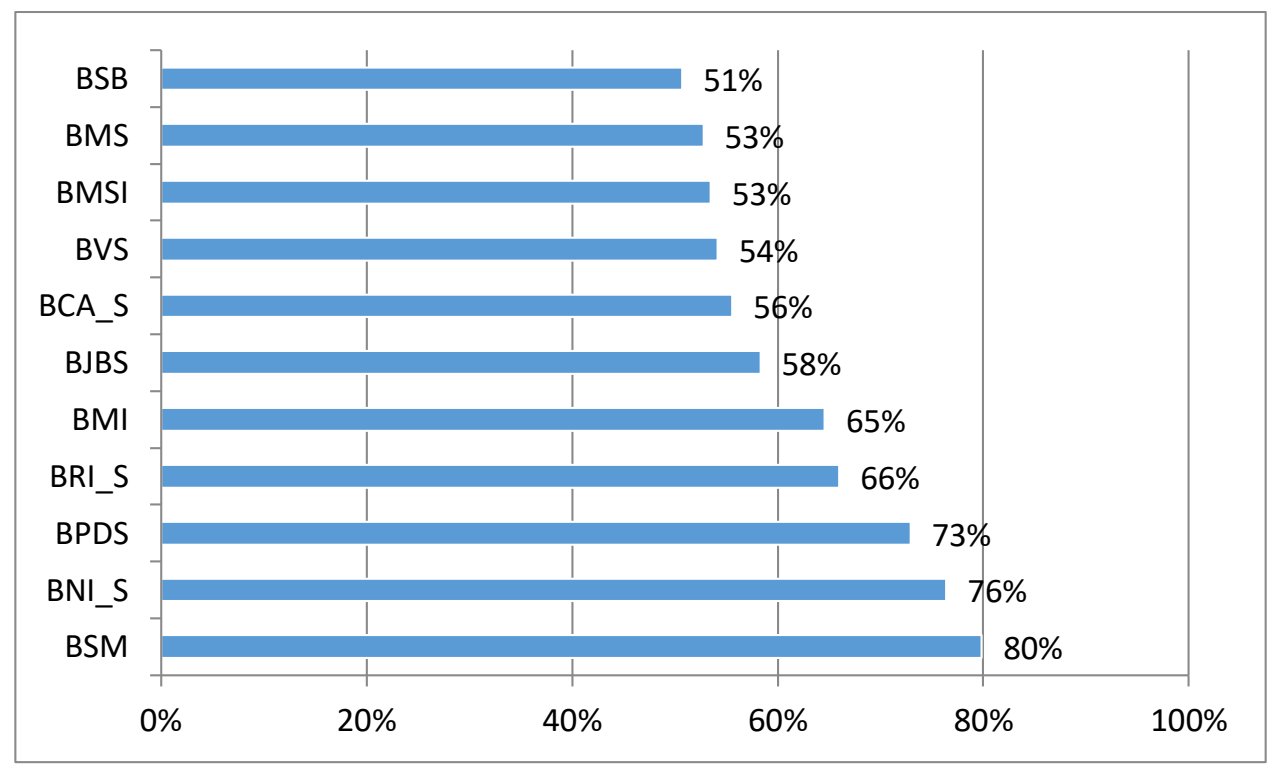

Figure 2. ISR Index Disclosure of Indonesian Sharia Banks in 2015-2017

Figure 2 indicates the mean of the percentage of ISR index in the Islamic commercial banks in 2015-2017 which was above 50\%. The top 3 Islamic commercial banks were BSM (80\%), BNI Syariah $(76 \%)$, and BPDS (73\%); while the bottom three were BSB (51\%), BMS (53\%), and BMSI (53\%). It was the evidence stating that the ISR disclosure index in the Islamic commercial banks in Indonesia in 2015-2017 was not optimal, due to eight of the eleven Islamic commercial banks were below $70 \%$. 
The ISR index used in this research covered 6 themes with 48 items. The first theme was finance and investment (six items), service and product (three items), worker (eleven items), social (ten items), environment (five items), and corporate governance (thirteen items). Figure 3 presented the data of ISR index score disclosure per theme in the eleven Islamic commercial banks in 2015-2017.

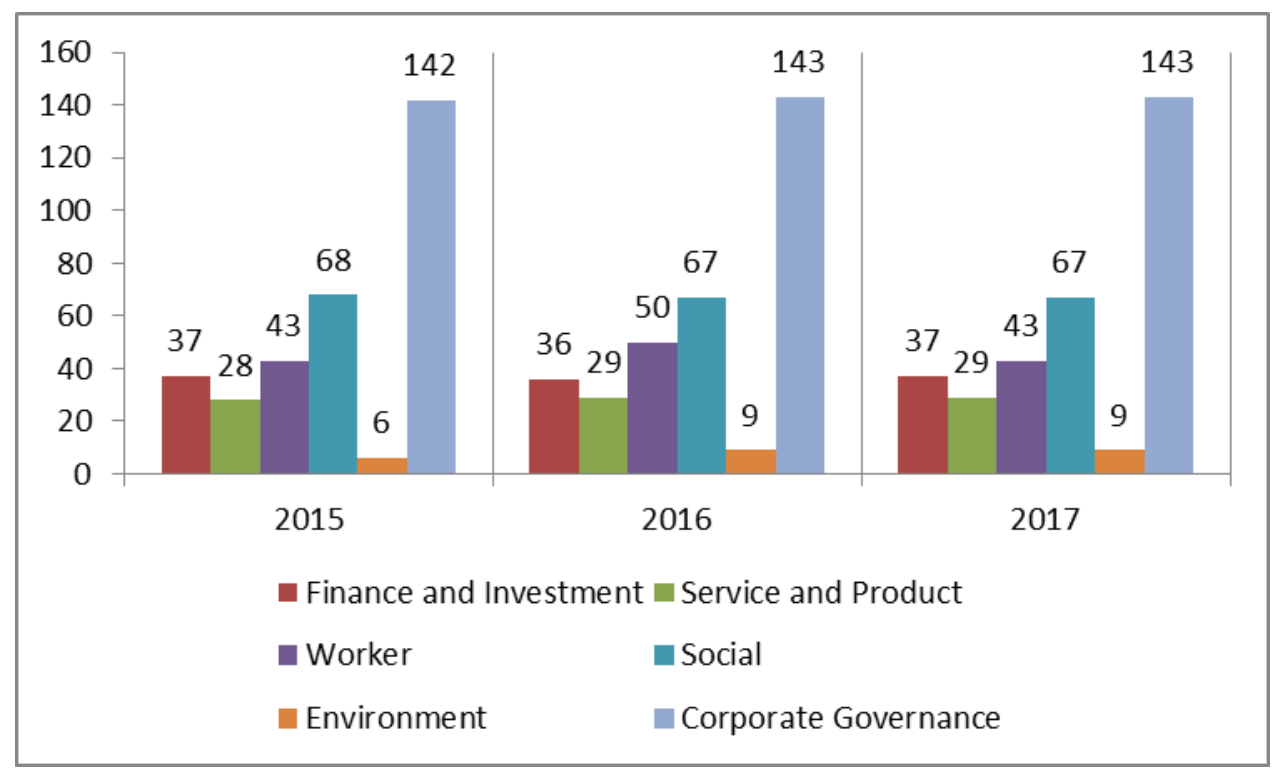

Figure 3. ISR Index Score of Each Theme

Figure 3 reveals the difference in index disclosure level per theme in each year. The finance and investment theme was similar throughout the years; whereas the service and product increased by one item, from 28 to 29 in 2016-2017. The corporate governance item was also similar. The item had the highest disclosure levels. Moreover, the result indicated that the environment theme was still neglected; while the theme was one of the urgent aspects of the Islamic principle. Good environment management determines next generation's future, which is the sustainability principle. The management was in line with the sustainable development goals (SDGs) which remain to be the main 
issue. Furthermore, figure 4 presents the percentage of ISR index per theme in the eleven Islamic commercial banks in 2015-2017.

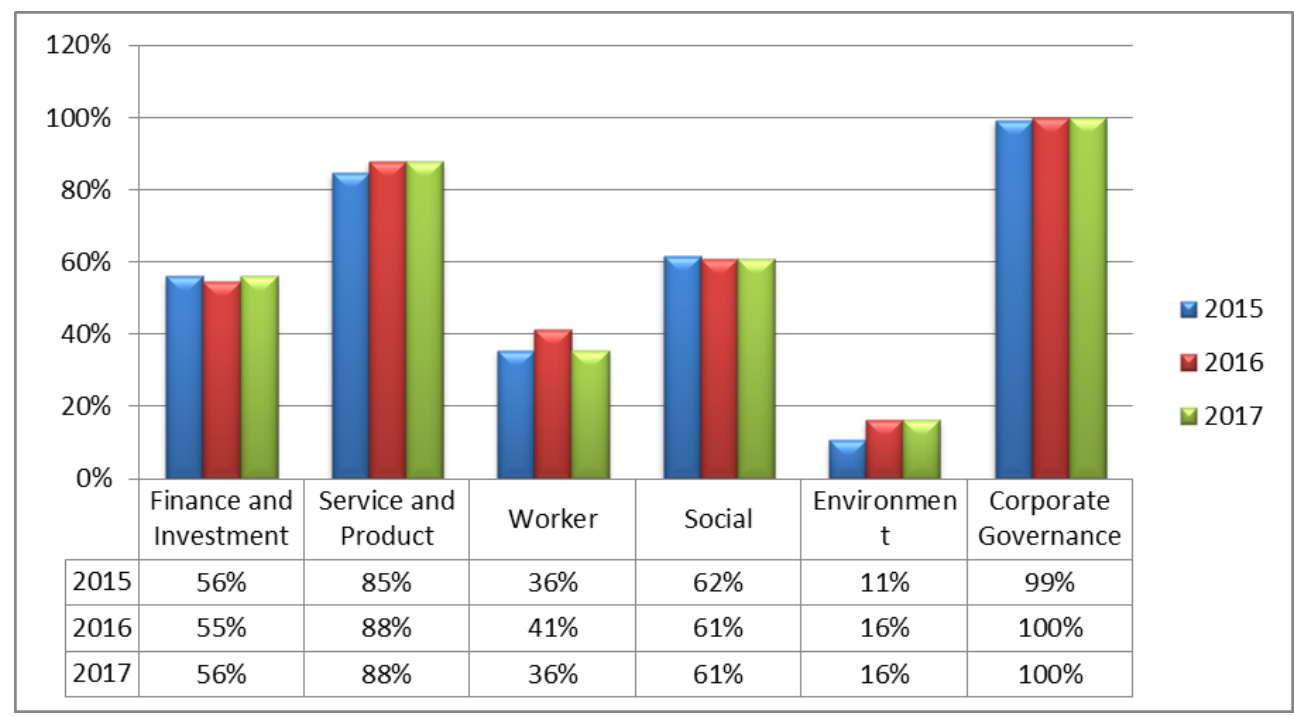

Figure 4. Percentage of ISR Index of Each Theme

As shown in the figure 4, the corporate governance theme had the highest level of ISR index disclosure, up to $99 \%$ in 2015 and $100 \%$ in 2016 and 2017. Meanwhile, the environment theme had the lowest level, only up to 11\% in 2015 and 16\% in 2016 and 2017. Moreover, the worker theme had the second-lowest level, which was around $36 \%$. The service and product theme had the second-highest level up to $88 \%$; whereas the rest, the level of finance and investmen and the social themes were $56 \%$ and $62 \%$ respectively.

\section{Discussion}

The trend of ISR index in this study concludes that Bank Syariah Mandiri obtained the highest score. This finding is different to the result of Putri et al., (2019) that conducted research from 2013 to 2017 in four Islamic commercial banks listed in stock exchange. Putri's et.al (2019) result showed that there was Bank Muamalat Indonesia (BMI) 
that reached the highest score in 2013, 2014, 2016, and 2017 with score between 30 up to 32 from 48 index points of ISR. In 2015, the highest score belongs to Bank Syariah Mandiri with 30 points.

Moreover, the result of this study is also different from the previous research finding by (Gustian \& Faisal (2015). They argue that in 2011-2013, the highest disclosure level was achieved by Bank Muamalat Indonesia; while the lowest was by Bank Panin Syariah (2012), Bank Victoria Syariah (2012), and Bank Bukopin Syariah (2013). In general, there is no Islamic banks that disclose social performance based on ISR index perfectly with $100 \%$ score. According to Sofyani et al., (2012), this may because of two factors: the banks did not conduct social activities that actually can be done and there was item measurement in ISR index that banks did not need to do. Moreover, Wahyuni, (2018) had a different result, that was in her research BNI Syariah was the highest score index about $63.94 \%$, and the lowest one was Maybank Syariah. The potential reason of the differences is because of the sample period employed in this research.

The latest regulation issued by the Financial Service Authority Number 51/POJK.03/2017 on the Implementation of Sustainable Finance in Financial Service Institution, Issuer, and Public Corporate is expected to increase the awareness of Islamic banks in Indonesia in terms of disclosure. The regulation does not mention any specific instruction to the sharia-based financial institutions. Nevertheless, the accountability and transparency principles in disclosure had been in accordance with the Islamic value.

The content analysis on the reports of the Islamic commercial banks in terms of the Islamic Social Reporting (ISR) index resulted in six themes with 48 disclosure items. The six themes are finance and investment, service and product, employee, social, environment, and corporate governance. According to previous studies, mostly the corporate governance theme also has 100\% score every year (Asriati et al., 2016; Sawitri et al., 2017a; Sofyani, Yogyakarta, et al., 2012). Otherwise, the result of research conducted by Meutia \& Febrianti 
(2017) shows that theme of corporate governance has average only $69 \%$. This different result might be caused by different sample and research periods. Most of previous studies also have found similar result that environment theme is the lowest score in ISR index (Asriati et al., 2016; Meutia \& Febrianti, 2017; Sawitri et al., 2017; Sofyani et al., 2012).

The first theme, finance and investment, constituded the identification of riba, gharar, zakat, investment, and funding project. The Islamic commercial banks made many discloses in the funding project, zakat, and investment; while the identification of usury and gharar was still rarely disclosed. Sofyani et al., (2012) stated that not all items were fully disclosed, such as customers that have problem with the banks. This should have been happened to keep customers' reputation in public. Some previous studies stated that not all Islamic banks disclose about riba and bad deb write-off policy (Asriati et al., 2016; Sofyani et al., 2012). In line to this, Sawitri et al., (2017) also explained that there was no disclosure about gharar and policy relate to postponing or reschedule from the creditors if they have problem with the payment. The Islamic banks only disclosed about punishment of delaying that become benevolence fund.

The second theme, service and product, was the theme that should acquire approval from the sharia supervisory board, including the definition of each product and the service for the consumers' complaint. However, the service was not completely disclosed by the Islamic commercial banks. Public should know about the complete information the services provided by the company. It is one of main goals in Islamic banks (Abdullah, 2010). Service on facing consumers' complaint was not explained clearly by some of Islamic commercial banks. Banking industry is about trust and service so that excellent service is the best way for Islamic banking to get the public trust. Disclosing how the Islamic banks manage their customers' complain is good for transparency. 
The third theme, worker, had eleven items, i.e. hours of work, off day, allowance, remuneration, training and education, equity, worker involvement, health and safety, working environment, and special group. Most disclosures were in the training and education for the employee. It was important to improve the corporate employees' performance and skills. Meanwhile, the least disclosed items were the employees' off day and hours of work. This results support the previous study conducted by Asriati et al. (2016) who found that $100 \%$ of education and training for employee was disclosed both in Indonesian and Malaysian Islamic banks for 2012-2014 period.

The fourth theme, social, included ten items which were donation, waqf, qardhul hasan (benevolence loan), volunteer, scholarship, work empowerment, capacity building for the young generation, improvement in the quality of life, concern for children, and supports for social activity. The theme was adequately disclosed by the Indonesian Islamic commercial banks. The mostly disclosed items were donation, social activities, and qardhul hasan. Moreover, the least disclosed items were waqf and volunteerism. This finding is supported by previous research that explain Islamic banking in Indonesia is aware of the importance of helping people by giving qardhul hasan, sadaqa, and other charities (Asriati et al., 2016).

The fifth theme, environment, consisted of five items which were living environment conservation, pollution, environmental education, environmental certification, and environmental management system. It was the least disclosed theme by the Islamic banks. Meanwhile, the result of this study depicts that the mostly disclosed item of this theme was the living environment conservation; while the least one was pollution. Several Islamic commercial banks had implemented the green office to save paper and moved on to the digitalized document. Asriati et al. (2016) also found that the disclosure of this theme was only $33.33 \%$ for Islamic banks in Indonesia and $48.48 \%$ for Islamic banking in Malaysia. Islamic banks has no direct relationship with the environment in the operational business, that may be caused the 
disclosure of this theme was the lowest than the other themes (Asriati et al., 2016).

Based on previous research conducted by Saridona and Cahyandito (2015), the Islamic banks does not implement social activities related to environment education or policies regarding green banking. Green banking is giving financing to companies engaged in the sector that has no bad impact on the environment and social condition of the community. Asriati et al., (2016) also stated that environment theme in ISR index has no direct relation with operational activities of Islamic banks but this condition can not become a barrier for Islamic banks to pay more attention to the environment. Islamic teachings guide Muslim to have good realationship with people and environment. Therefore, be cautious to the environment is an important thing to do in any Islamic institution including Sharia banks. Sofyani et al., (2012) also state that there is no Islamic bank that implements the policy about environmental audit and green product during 2009 to 2010.

The sixth theme, corporate governance, consisted of thirteen disclosure items. It was the theme with the highest disclosure level per year, almost $100 \%$. Besides, the theme disclosure was made and mentioned in the separated document which was Good Corporate Governance (GCG). The reporting document also included relevant self-assessment that resulted in the governance criteria of each corporate. GCG is important in building public trust and international scope as a mandatory for banking industry to be well-developed. GCG consists of a set of relationship between management, shareholder, director board, and other stakeholders (Abdullah, 2010). Therefore, GCG needs to be implemented and disclosed.

The urgency of CSR performance and disclosure for economic sustainability have been discussed by Arshad et al. (2012). ISR index can be an important resource of companies and become a strategic tool in meeting stakeholders' expectation. The disclosure can provide information beyond financial performance of the company that give 
impact for people and environment. Unfortunately, this study also found similar thing with previous studies that conducted by Saridona \& Cahyandito (2015) that Indonesian Islamic banks have no more concern to the environment conservation activities, but they have focused on social activities relate to the community and education improvement.

The results of this study significantly contribute to the development of Islamic banks. Recommendations and suggestions are available for banking companies, especially in terms of corporate social responsibility disclosure. Moreover, the results describe potential longterm impact of the disclosure on the corporate, and may provide suggestions in terms of references that the Islamic banks may use. Furthemore, the research results are expected to provide an overview of the understanding for Islamic banking on the urgency of sharia compliance. Islamic banking also needs to understand the urgency of the need to prepare standardized disclosure reports that are more relevant by using the ISR index as a convergence of the Global Reporting Initiative (GRI) index. This ISR will later need to be regulated in further discussion by regulators and standard setters such as Accounting and Auditing Organization for Islamic Financial Institution (AAOIFI), Indonesian Accountant Association (IAI), Financial Service Authority (OJK), and other related institutions.

\section{Conclusion}

The results of this study show that the level of Islamic Social Reporting (ISR) disclosure of Indonesian Islamic banks is fluctuating during the years of 2015 to 2017. Each Islamic bank possesses different characters while disclosing the delivered report. However, the six themes of ISR index have not optimally been disclosed by the Islamic banks. Therefore, such disclosure should be improved. Regulations and recommendations from the Indonesian Islamic banking association and regulators are highly necessary to support the improvement. The ISR disclosure objective is also to support the 
implementation of maqasid syariah concept and the realization of Sustainability of Development Goals (SDGs) through various social and environmental-based activities.

This research provides additional empirical literature related to the social responsibility disclosure using the Islamic Social Reporting (ISR) index. In managerial implication, the research constitutes the urgency of sharia-based financial institution disclosure standardization in Indonesia which is referred to the relevant international organizations. It is crucial to make sharia-based financial institution, especially Islamic commercial banks develop standardized transparent disclosure which informs both benefits and value-added of Islamic banks in the eye of public and customers. Therefore, future research may add length of observation period to broaden the analysis and estimate the trend of Islamic commercial banks in general. In addition, future inquiries may also compare the disclosure regulation and the level of Islamic commercial banks among countries using the similar index.

\section{Acknowledgement}

The authors would like to express gratitudes for Research and Community Service Institution (Lembaga Penelitian dan Pengabdian Masyarakat) of Universitas Ahmad Dahlan Yogyakarta Indonesia for supporting and funding this research.

\section{References}

Abdullah, M. A. (2010). Corporate Governance: Perbankan Syariah di Indonesia. Yogyakarta: Ar Ruzz Media Group.

Arshad, R., Othman, S., \& Othman, R. (2012). Islamic Corporate Social Responsibility, Corporate Reputation and Performance. International Journal of Social, Behavioral, Educational, Economic, Business and Industrial Engineering, 6(4), 643-647.

Asriati, R., Ulfah, P., \& Setyorini, C. T. (2016). Analisis Perbandingan Komponen Islamic Social Reporting (ISR) Pada Bank Syariah antara Negara Indonesia dan Malaysia. Simposium Nasional 
Akuntansi XIX, Lampung, 1-24.

Bengtsson, M. (2016). How to Plan and Perform A Qualitative Study Using Content Analysis. NursingPlus Open, 2, 8-14. https://doi.org/http://dx.doi.org/10.1016/j.npls.2016.01.001

Bukair, A., \& Rahman, A. (2015). The Effect of the Board of Directors'

Characteristics on Corporate Social Responsibility Disclosure by Islamic Banks. Journal of Management Research, 7(2), 506-519.

Chapra, M., \& Ahmed, H. (2002). Corporate Governance Lembaga Keuangan Syariah. Jakarta: PT Bumi Aksara

Effendi, M. A. (2009). The Power of Good Corporate Governance: Teori Dan Implementasi. Jakarta: Salemba

Elkington, J. (1997). The triple bottom line of 21 st century business Cannibals with forks. Environmental Quality Management, 8(April), 424. https://doi.org/10.1002/tqem.3310080106

Farook, S., Hasan, M. K., \& Lanis, R. (2011). Determinants of Corporate Social Responsibility Disclosure: The Case of Islamic Banks. Journal of Islamic Accounting and Business Research, 2(2), 114-141.

Firmansyah, I. (2014). Bank Muamalat Indonesia and Bank Syariah Mandiri ISR Sebagai Proksi Pengungkapan CSR Bank Muamalat Indonesia dan Bank. Jurnal Ilmiah ESAI, 8(1), 23-40.

Grais, W., Pellegrini, M. (2006). Corporate Governance and Shariah Compliance in Institutions Offering Islamic Financial Services. Policy. Research Working Paper No. 4054. World Bank, Washington, DC. https://openknowledge.worldbank.org/handle/10986/8901 License: CC BY 3.0 IGO.

Gray, R., Kouhy, R., \& Lavers, S. (1995). Corporate social and environmental reporting $A$ review of the literature and a longitudinal study of UK disclosure. Accounting, Auditing $\mathcal{E}$ Accountability Journal, $\quad 8(2)$, 47-77.

https://doi.org/10.1108/09513579510146996

Gustian, V., Faisal, F., \& Diponegoro, U. (2015). Analisis Perbandingan Penggunaan Gri Indeks Dan Isr Indeks Dalam Pengungkapan Tanggung Jawab Sosial Perusahaan Perbankan Indonesia Tahun 2010 - 2013. Diponegoro Journal of Accounting, 4(4), 1-10. 
Haniffa, R. (2002). Social Reporting Disclosure: an Islamic Perspective. Indonesian Management and Accounting Research, 1(2), 128-146.

Harahap, S. S. (2011). Teori Akuntansi. Jakarta: Rajawali Pers.

Indriantoro, N., \& Supomo. (2014). Metodologi Penelitian Bisnis untuk Akuntansi dan Manajemen. Yogyakarta: BPFE.

Iqbal, Z., \& Mirakhor, A. (2004). lders Model of Governance in Islamic Economic System. Islamic Economic Studies, 11(2), 43-63.

Jati, K. W., Agustina, L., Muliasari, I., \& Armeliza, D. (2020). Islamic social reporting disclosure as a form of social responsibility of Islamic banks in Indonesia. Banks and Bank Systems, 15(2), 47-55. https://doi.org/10.21511/bbs.15(2).2020.05

Kamla, R., \& Rammal, H. G. (2013). Social reporting by Islamic banks: Does social justice matter? Accounting, Auditing and Accountability Journal, 26(6), 911-945. https:/ / doi.org/10.1108/AAAJ-03-20131268

Lidyah, R., Amir, A., Yacob, S., \& Rahayu, S. (2019). The Effect of Board of Director, Board of Commissioner and Audit Committee on Value of Firm to Islamic Social Reporting as A Mediating Variable. Journal of Business Studies and Management Review (JBSMR), 2(2), 82-87. https:// doi.org/10.22437/jb.v2i2.7214

Maali, B., Casson, P., \& Napier, C. (2006). Social reporting by islamic banks. Abacus, 42(2), 266-289. https://doi.org/10.1111/j.14676281.2006.00200.x

Meutia, I., \& Febrianti, D. (2017). Islamic Social Reporting in Islamic Banking: Stakeholders Theory Perspective. SHS Web of Conferences, 34(December), 12001. https://doi.org/10.1051/shsconf/20173412001

Mosaid, F. E., \& Boutti, R. (2012). Relationship between Corporate Social Responsibility and Financial Performance in Islamic Banking. Research Journal of Finance and Accounting, 3(10), 93-105. Nasution, M., Setyanto, B., Huda, N., Mufraeni, M., \& Utama, B. (2006). Pengenalan Eksklusif Ekonomi Islam (First). Depok: Kencana.

Nurkhin, A. (2010). Corporate Governance dan Profitabilitas; 
Pengaruhnya terhadap Pengungkapan CSR Sosial Perusahaan. Jurnal Dinamika Akuntansi, 2(1), 46-55.

Othman, R., \& Thani, A. M. (2010). Islamic Social Reporting Of Listed Companies In Malaysia. International Business $\mathcal{E}$ Economics Research Journal (IBER), 9(4), 135-144. https://doi.org/10.19030/iber.v9i4.561

Othman, R., Thani, A. M., \& Ghani, E. K. (2009). Determinants of Islamic Social Reporting among Top Shariah-Approved Companies in Bursa Malaysia. Research Journal International Studies, 12, 4-20.

Otoritas Jasa Keuangan. (2017). Regulation of Financial Service Authority Number 51/POJK.03/ 2017.

Putri, A. K., Fitriyanti, E., Sulistiana, I., Fahria, I., \& Hidayati. (2019). The effect of islamic social reporting index on islamic banking financial performance in indonesia. Humanities and Social Sciences Reviews, 7(4), 609-616. https:/ / doi.org/10.18510/hssr.2019.7481

Putri, T. K. (2014). Faktor-Faktor Yang Mempengaruhi Islamic Social Reporting Perusahaan-Perusahaan Yang Terdaftar Pada Indeks Saham Syariah Indonesia (ISSI) Tahun 2011-2012. Thesis: Universitas Diponegoro.

Qoyum, A., Mutmainah, L., Setyono, J., \& Qizam, I. (2017). The Impact of Good Corporate Governance, Company Size and Corporate Social Responsibility Disclosure: Case Study of Islamic Banking in Indonesia. Iqtishadia: Jurnal Kajian Ekonomi Dan Bisnis Islam, 10(1), 130-159. https://doi.org/dx.doi.org/10.21043/iqtishadia.v10i1.2365

Saridona, R., \& Cahyandito, M. F. (2015b). Social Performance of Indonesia Islamic Banking: Analysis of Islamic Social Reporting Index. In First International Conference on Economics and Banking (ICEB-15) (pp. 194-200). Atlantis Press. https:// doi.org/10.2991/iceb-15.2015.29

Sawitri, D. R., Juanda, A., \& Jati, A. W. (2017). Analisis Pengungkapan Corporate Social Responsibility Perbankan Syariah Indonesia Berdasarkan Islamic Social Reporting Index. Jurnal Reviu 
Akuntansi Dan Keuangan, 7(1), 983-992.

Sofyani, H., Ulum, I., Syam, D., \& Latifah, S. W. (2012). Islamic Social Reporting Index sebagai Model Pengukuran Kinerja Sosial Perbankan Syariah (Studi Komparasi Indonesia dan Malaysia). Jurnal Dinamika Akuntansi, 4(1), 36-46.

Tapanjeh, A. (2009). Corporate Governance from the Islamic Perspective: A Comparative Analysis with OECD Principles. Critical Perspectives on Accounting, 20, 556-567.

Trisnawati, R. (2014). Pengaruh Ukuran Perusahaan, Profitabilitas, Leverage, Ukuran Dewan Komisaris dan Kepemilikan Manajerial Terhadap Pengungkapan Corporate Social Responsibility (CSR) Industri Perbankan di Indonesia. In Seminar Nasional dan Call For Paper (pp. 369-385).

Wahyuni, S. (2018). Islamic Social Reporting Disclosure and Determinant Factors: Empirical Evidence from Islamic Banks in Indonesia. 5th International Conference on Community Development (AMCA). 231, 389-392. https://doi.org/10.2991/amca18.2018.107

Wardani, M. K., \& Sari, D. D. (2019). Disclosure of Islamic Social Reporting in Sharia Banks: Case of Indonesia and Malaysia. Journal of Finance and Islamic Banking, 1(2), 105. https://doi.org/10.22515/jfib.v1i2.1495 